Logos Universality Mentality Education Novelty, Section:

Political Sciences and European Studies

ISSN: 2284 - 5992 (print), ISSN: 2284 - 5992 (electronic)

Covered in: CEEOL, Index Copernicus, Ideas RePeC, EconPapers, Socionet

\title{
EEAS AT THE BEGINNING OF XXIST CENTURY: SOME INSTITUTIONAL INNOVATIONS IN EU DIPLOMACY
}

\author{
Madalina Virginia ANTONESCU
}

$$
\text { DOI: }
$$

http://dx.doi.org/10.18662/lumenpses.2015.0301.03

Logos Universality Mentality Education Novelty, Section: Political Sciences and European Studies, 2015, Volume III, Issue

$$
\text { 1, pp: } 35-47
$$

$$
\begin{aligned}
& \text { Published by: } \\
& \text { Lumen Publishing House } \\
& \text { On behalf of: }
\end{aligned}
$$

Lumen Research Center in Social and Humanistic Sciences 


\title{
EEAS at the Beginning of XXI ${ }^{\text {st }}$ Century: Some Institutional Innovations in EU Diplomacy
}

\author{
Madalina Virginia ANTONESCU ${ }^{1}$
}

\begin{abstract}
Even since its beginnings, the EU manifested a constant concern for the development of a specific foreign policy pillar, at an institutional and strategic level, able to surpass the national one. This ambitious vision was progressively extended from a classical approach over foreign policy (a multilateral one, based on cooperation among the EU member states, within a field seen as "traditionally national"), towards a postmodern approach, with obvious supra-state elements. Today, EU diplomacy looks like one of the fundamental pillars of the "United Europe" concept, of the "Union" as distinct centre of power, with ambitions in developing a global strategic vision within the foreign policy field, at international level. The paper begins with the current EEAS organization, adding certain institutional innovations about EU diplomacy at the beginning of $21^{\text {st }}$ century and about the way in which the general perception of EU, as global actor, could be improved.
\end{abstract}

Keywords: EU diplomacy, EEAS, EU institutions, EU foreign policy, institutional reforms.

1 Ph.D, scientific researcher, Romanian Diplomatic Institute, Romania, madyantonescu@gmail.com. 


\section{Introduction. Legal Grounds for the Setup of EEAS: Treaty of Lisbon and Council Decision from 2010}

Legal consecration of the European External Action Service, as institutionalization of diplomacy in the Union, is made through art. 13a, paragraph 3/TUE, amending the Lisbon Treaty, which specifies that the High Representative of the Union for external affairs and security policy is supported to exercise its mandate as "European External Action Service". Its componence is established by the officers of the competent services of the Secretary-General of the Council (Council of Ministers) and of the European Commission (a supranational dimension of EEAS, from this viewpoint). To this, we add the national dimension of the EEAS componence (also including detached personnel from the diplomatic services of the EU member states). In addition, the national dimension also occurs in the concrete activity of $E E A S$, which works in cooperation with the diplomatic services of the member states. Therefore, despite its supranational attributions of representing the EU diplomatic interests and strategies, not of the member states, EEAS is not entirely detached from the national dimension (regarding its concrete activity).

The legal nature of EEAS, according to the Treaty of Lisbon, is therefore a mixed one, in our opinion, from the viewpoint of its organization, of its structure and concrete activity.

The supranational aspect is provided by the fact that it is a body directly setup through an EU treaty (a fundamental legal document for the EU rule of law), subordinated to the High Representative (a de facto Minister of External Affairs). EEAS is not subordinated to the European Commission or to any other EU institution; instead, art. 13a/TEU modifying the Treaty of Lisbon includes a vague mentioning about this service: "supports the High Representative, in exercising its mandate". The legal term "support" can have various legal interpretations (especially since the creation of EEAS follows a special procedure, at EU level, involving almost all the EU institutions: European Commission, European Council, European Parliament, Council of Ministers). Thus, the organization and functioning of EEAS are determined through decision made by the Council (Council of Ministers), while the institution with the decision-making power is the other Council (European Council, based on the proposal presented by the High Representative). The European Council decides after consulting the European Parliament and it must have the approval of the Commission. Therefore, it is a rather complicated procedure, entailing to various degrees 
both EU institutions of clear supranational dimension (the Commission, the High Representative, and the European Parliament) and of intergovernmental dimensions (Councils). Therefore, from the perspective of its organization and operation, we can talk about a mixed legal regime, determined from the start for EEAS, for the Treaty of Lisbon.

Concerning the legal grounds created subsequently, starting from the provisions of the Treaty of Lisbon, we must mention the decision of the EU Council no. 1165/10 dated July 20 $0^{\text {th }} 2010$, Brussels, establishing the organization and operation of EEAS, as well as the resolution of the European Parliament no. P7_TA (2009)0057, called "The institutional aspects of setting up the European External Action Service" (2009/2133(INI)), dated October $22^{\text {nd }} 2009$.

According to this document, the role of EEAS is to be complementary to the diplomatic representations of the EU member states, without bringing all of them into discussion; to highlight the EU role in the world, to enhance the visibility of $\mathrm{EU}$ and to strengthen its actual capacity, on the international arena. Another important aspect in this document, regarding the EU institution with which EEAS would be more connected, refers to the fact that it is "a service that is sui generis from an organisational and budgetary point of view", but which "must be incorporated into the Commission's administrative structure" (letter N. Item $7 /$ resolution). In addition, the European Parliament recommends taking into consideration the fact that EEAS "is subject to the decisions of the Council in the traditional fields of external policy (CFSP and the common security and defence policy) and subject to the decisions of the College of Commissioners in the field of common external relations".

On the contrary, from the perspective of the decision made by the

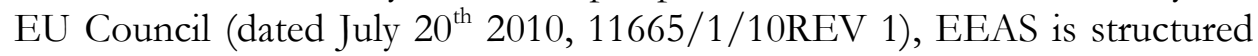
as an autonomous body of the EU, in relation to the European Commission.

Another legal status ambiguity occurs in the decision of the EU Council, in the Preamble, item 1, where EEAS is regarded as "a functionally autonomous body of the Union under the authority of the High Representative", while the role of the Service will be (as a reiteration of the provisions of the Lisbon treaty) to "support the High Representative, who is also a Vice-President of the Commission and the President of the Foreign Affairs Council, in fulfilling his mandate to conduct the Common Foreign and Security Policy ("CFSP") of the Union and to ensure the consistency of the Union's external action". 
Further on, in art. 1, paragraph 2 ("Nature and scope of Creating EEAS"), de decision issued by the EU Council sees in EEAS "a functionally autonomous body of the European Union" - not of the Commission "separate from the General Secretariat of the Council and from the Commission with the legal capacity necessary to perform its tasks and attaints objectives, placed under the authority of the High Representative of the Union for Foreign Affairs and Security Policy". According to art. 1, it has a mixed structure (central administration and the so-called EU embassies, called "Union Delegations to third countries and to international organisations"), which suddenly brings into discussion the legal perspective of EEAS, from the level of certain EU organism, to the profile of an authentic Ministry of Foreign Affairs of the Union, therefore an important supra-national aspect (in terms of its operation status, its attributions, its competence).

An important aspect, in the correct operation of EEAS (as organism of mixed or double legal nature, both with supra-national elements and with intergovernmental elements) is to also mention item 12 of the Council Decision, which allows for a wider connection, at expertise level, between EEAS and the diplomatic plan of the EU member states. Thus, in specific cases, EEAS can turn to national experts, that will work directly subordinated to the High Representative, for these determined cases (for example, such as finding solutions on the medium and long term, in the "immigrants' crisis file", a multi-dimensional and complex problem, requiring several types of analysis, as well as continuous, effective and constant cooperation between the EEAS level of expertise and diplomacy and that of the member states). In our opinion, this provision represents a highly adequate method to find diplomatic solutions, based on a harmonization of the diplomatic positions of the EU member states, with the ones offered by EEAS. In addition, according to art. 3 paragraph 1/EU Council Decision, a strong connection is created between the EEAS activity and the diplomatic services in the EU states (the EEAS has the role of supporting and cooperating with these national services), as well as between the EEAS activity and organisms of the EU institutions (with the General Secretariat of the Council, with the Commission services), in order to ensure coherence among the various areas of the external action of the Union.

\section{EU Role as Global Actor: Towards a Global EU Diplomacy}

From the very preamble of the Treaty of Lisbon, establishing the "new EU", the document sets distinct global roles, for this original political entity: 
- art. 2, paragraph 5/TEU, amending the Treaty of Lisbon (regarding the "EU relations with the rest of the community", in which the EU takes upon to assert and promote its values and interests, to contribute to the peace, security, durable development of the planet, to the solidarity and mutual respect among peoples, to a fair and free trade, elimination of poverty and protection of human rights, strictly observing and developing international law and observing the principles of the UN Charter)

- art. 9D/TEU, amending the Treaty of Lisbon: attribution of the Commission to promote the general interest of the Union and to ensure the foreign representation of the Union (with the exception of the common foreign and security policy)

- art. 10A, paragraph 1/TEU, amending the Treaty of Lisbon, through which the Union (another dimension of its nature of "global actor", assumed at the level of founding treaties) assumes the role to "develop relations and build partnerships with third countries and regional and global international organization, sharing the EU principles, of promotion of human rights, democracy, state de jure, observance of human dignity, principles of equality and solidarity, observance of the UN Charter and international law".

- art. 10C/TEU, amending the Treaty of Lisbon (in terms of common foreign and security policies), through which "the Union acts on the international stage", according to the principles stipulated above

- The Union has competence in all the fields of foreign policy and in all matters concerning the Union security, including the gradual definition of a common defence policy, which can lead to a common defence (paragraph 1, new art. 11/TEU, amending the Treaty of Lisbon)

- through art. 24/TEU, amending the Treaty of Lisbon, the EU can conclude agreements with one or several international states or organizations, in the fields of common foreign and security policy

- art. $46 \mathrm{~A} / \mathrm{TEU}$, amending the Treaty of Lisbon (granting the European Union legal personality); as a consequence, among others, the EU can be part of the European Convention of Human Rights and Fundamental Freedoms, with a distinct position in the UN (art.19, paragraph 2, paragraph 3/TEU), amending the Treaty of Lisbon, which stipulates that, after EU defines a position in the subject on the agenda of the UN Council of Security, the member states included in this UN organism bave the obligation to request that the High Representative be invited at the Council of Security, to present the position of the Union. This signifies a clear supranational dimension, in the EU diplomacy, as well as outlining the EU profile, as "global actor")

- in the same manner, art. 16 letter b/TEU, amending the Treaty of Lisbon, emphasises EU's global actor profile (adding the obligation of the 
EU member states, in the PESC field, to consult the other EU states, at the European Council or the Council (of Ministers), before taking any action on the international scene or to assume any engagement - on the same scene which might bring prejudices to the interests of the Union. It is therefore an obligation of diplomatic loyalty or action on the international scene (in the PESC field) of the EU member states, as well as a provision strengthening the supranational dimension and the scope of global action of the Union.

- consolidation of the role of the European Commission President, in terms of attributions and procedure of election (art. 9R, paragraph $7 / \mathrm{TEU}$, on the Treaty of Lisbon), (a supranational legal institution, with attributions related to the EU representation abroad)

- if the matter in question concerns the field of common foreign and security policy (chapter II, section 1/TEU, amending the Treaty of Lisbon), then only in terms of this policy and if a common approach of the Union was defined in the European Council or in the Council (of Ministers), does the High Representative of the Union for foreign affairs and security policy and the Ministers of Foreign Affairs of the EU member states coordinate their activities at the Council (of Ministers), according to art. 16, letter b/TEU, amending the Treaty of Lisbon. This dimension concerning the coordination of policies in the PESC field is also strengthened by the action of the EU diplomacy at international level, i.e. in relation to third countries (the diplomatic missions of the EU member states and the EU delegations in the third countries cooperated and contribute to phrasing and enforcing the common approach", according to art. $16 \mathrm{c} / \mathrm{TEU}$, amending the Treaty of Lisbon).

- consecration de facto of a supranational institution, that of the High Union Representative for foreign affairs and security policy (who is also one of the VicePresidents of the Commission, attribution through which he/she ensures the coherence of the Union's foreign actions, according to art. 9D, paragraph 4 and article 9R, paragraph 4/TEU, amending the Treaty of Lisbon). The High Representative is appointed by the European Council (art. 9E, paragraph $1 / \mathrm{TEU}$, amending the Treaty of Lisbon), leads the common foreign and security policy of the Union (art. 9R, paragraph 2/TEU, modifying the Treaty of Lisbon) and chairs the Council of Foreign Affairs, body within the EU Council (Ministers of the EU member states). Practically, the High Representative has the attributions of the EU Minister of Foreign Affairs, provisioned in the Constitutional Treaty of Rome, rejected in 2005. It can be said that the High Representative, consecrated through the Treaty of Lisbon is de facto, an EU Minister of Foreign Affairs, with supranational attributions and profile (participating in the works of the European Council, political 
institution at the level of chiefs of states, within the EU - according to art. 9B/TEU consolidated).

- Part V/TFEU, amended through the Treaty of Lisbon, called "Foreign action of the Union" consolidates the EU competences and roles, at international level, in relation to the provisions of TEU (from the common trade policy, to restrictive measures, cooperation with third countries and humanitarian help, international agreements, relations of the Union with international organizations and third countries).

- the Union, as global actor, develops a policy of "cooperation for development", in the relation with the third states, in the mutual completion and support of the EU member states and with the main purpose of eradicating poverty at global level (art. $188 \mathrm{D} / \mathrm{TFEU}$, amending the Treaty of Lisbon).

- role of the Union, as global actor, to develop a policy of "economic, financial and technical cooperation (including assistance, with emphasis on the financial domain) with the third countries, other than the developing countries", subject to art. $188 \mathrm{H} / \mathrm{TFEU}$, amending the Treaty of Lisbon. According to this article, the actions of the Union and of the member states complete and support each other.

- role of the Union, as global actor, to develop actions "in the field of bumanitarian belp" (art. $188 \mathrm{~J} / \mathrm{TFEU}$, amending the Treaty of Lisbon), envisaging the provision of assistance and help to the population in third countries, which are victims of natural catastrophes or catastrophes caused by the human being and their protection, by fulfilling the humanitarian needs which may occur. The EU member states and the Union provide mutual completion and support, in this field as well (a combination of competencies, which render this domain mixed as well, without questioning the quality of global actor of the Union, rather emphasizing the originality of the action and its legal nature, in relation to any other international organization).

- in addition, also concerning the Union's role of global actor, art.188L, paragraph 1/TFEU, amending the Treaty of Lisbon, stipulates the competence of the Union to conclude agreements with one or several third countries or international organizations; art. $188 \mathrm{P} / \mathrm{TFEU}$, amending the Treaty of Lisbon, sets the Union's competence to "set any form of useful cooperation", with international organizations.

- The Union acts as a global actor (in third states and in relation to international organizations), through delegations under the authority of the High Representative and in close cooperation with the diplomatic and consular missions of the member states (art. $188 \mathrm{Q} / \mathrm{TFEU}$, amending the Treaty of Lisbon). 


\section{Certain Institutional Innovations regarding the EU Diplomacy, in the Light of the "Crisis of Immigrants" and more}

The crisis of immigrants, which began at the end of August 2015, took by surprise a large part of the EU diplomacy (at the level of visions, quick institutional reaction, shaping strategies of quick identification and prevention of the causes of massive exodus of immigrants towards the EU and within the EU). Instead of identifying solutions at EU level, the EU member states, overwhelmed by the sudden and massive inflow of immigrants, in waves, took quick measures at national level, when approaching this matter, some denouncing de facto fundamental agreements for the setting and safeguarding the Southern borders, as well as for the optimal functioning of the "space of security, freedom and justice" within the EU (Dublin Agreement, Schengen Agreement).

Certain quick measures were suggested in the speech of the European Commission President, Jean Claude Juncker (Juncker, Foster, Holehouse, 2015; Jucker, 2015), read at the European Parliament, on September $8^{\text {th }} 2015$; however, they are far from the crystallization of thorough strategies, on the medium and long term, for the EU (if it assumes a role of "global actor", therefore it intends to create a dynamic, active European diplomacy and not to settle for a passive role, that of "fatalistic acceptance" of the massive inflow of immigrants - as indicated by the reaction of the Commission, which ends up imposing all sorts of mechanisms to the states, of "mandatory and permanent quotas of refugees" (Juncker, Foster, Holehouse, 2015; Jucker, 2015) ${ }^{2}$, for lack of a better solution).

In the matter of the crisis of immigrants, we not - at least for the moment - the lack of visions, of innovative ideas, of in-depth approaches, coherent strategies, which EEAS should have generated, if we wish to talk about the EU, in a proactive diplomatic position, about a Union in control of the situation, not online inside the borders of its space of freedom, security and justice, but also in the areas generating massive migration towards Europe.

Thus, EEAS was supposed to elaborate and propose to the competent EU institutions, in due time, EU strategies which pay the issue of the immigrants' crisis special attention (political, financial, of prevention of crime and illegal immigration; measures to consolidate the role, attributions, funds

\footnotetext{
2 Also see the imposing of the "mandatory quota of immigrants" mechanism in the EU countries, despite the opposition of some of them, at the JAI Council on September 22 nd 2015, following the lack of consensus at the previous JAI Council, on September $14^{\text {th }} 2015$, on the same subject.
} 
granted to FRONTEX, strategies to strengthen and better secure the Southern borders of the EU; coherent EU policies to direct European funds to the EU countries in the South, as well as to the extra-European countries considered "safe"; EU policies to counter illegal immigration and the phenomenon of trans-national crime, especially trafficking in people towards Europe) etc.

In terms of such a long-term phenomenon (migration of extra-European populations, in massive waves, towards the heart of Europe - states such as Germany, Austria, Sweden etc. being the main destination of such waves), at the level of the $E U$, we propose the following:

- The EU diplomacy (EEAS through the High Representative) should propose a right to durable prosperity, which is consecrated at the UN level and acknowledged by the states, both at individual and at collective level (by the peoples). Thus, in the sense of this right (representing a legal stage superior to the rights to subsistence, such as the right food, the right to drinking water, for the domestic needs and for hygienic purposes, the right to shelter etc.), the states, the great powers and the international organizations - especially the economic organizations - would work on the creation of regional plans of financial support and implementation of certain environment-friendly industries, of certain green economies, in the extraEuropean areas, as well (not only the economies of the First World, of the developed Occidental states should benefit from the right to durable development), including for reasons of long-term cessation of the migration inflows to the First World. Prosperity is not "reserved" for the First World; in the $21^{\text {st }}$ century (as a century of abundance, but not of exaggerated consumption, a century of management, preservation, wise, long-term, durable cultivation of the planet's resources ), it must also become a right or a situation to which young populations, in demographic explosion, from the extra-European continents, have access. Only by ensuring "national or regional blocks of durable prosperity", will these populations no longer be interested in massively migrating to the First World (regarded as "an island of prosperity, in an ocean of global poverty"). The $21^{\text {st }}$ century must change the essence of its vision (currently monopolized by the wealthy North) of the global prosperity and globalization.

- Elaboration of an EU strategy specially designed for the management of situations of massive exoduses of extra-community populations, to and from the EU space 
- Elaboration of a specially designed strategy for strengthened relations between the EU and countries considered safe for immigration, from the extra-community space (Iran, Turkey, Lebanon and Jordan), called "EU partners for the management of migrations"

- Given the self-assumed role of the EU, as "global actor, in a world functioning more and more on the basis of the paradigms of dialogue/conflict between civilizations", we propose the creation of an EU Council of the Ministers of Culture, from the EU member states (as JAI is currently), which handles the identification of the European elements and European cultural strategies, which can outline a distinct cultural profile of the EU in the world, among the other civilizations of the planet, as distinct cultural actor (creation of a global perception of "an EU culture", which cannot be a merely political one, in the sense of art. $1 /$ TEU, amending the Treaty of Lisbon).

\section{- Founding of the EU Institute of Inter-civilization Relations} (studying the contact elements, the common areas among the major civilizations of the globe and organizing based on this information political and cultural paradigms for peaceful coexistence among the global cultural actors of the $21^{\text {st }}$ century).

- Founding of the EU Institute of European-Islamic Relations (given the issues of understanding, perception, civilization and religious integration of the immigrants coming from these areas) and reinventing an European policy of multiculturalism, also taking into consideration the necessity to form and consolidate the European identity, as such.

- Founding of the Institute of European Identity, subordinated to the Commission, due to its field of activity and its supranational componence (as well as to the EU role, as "distinct and global cultural actor"), to research from the cultural viewpoint the wealth and diversity of the European cultural heritage, in the European cultural diplomacy, outlining a series of cultural manifestations at international level, where the $E U$ is a distinct actor, the most representative elements in the European culture, both from the historic culture and from the present culture, marking its individuality at global level.

- Founding of the Institute of EU Diplomacy, directly subordinated to the High Representative of the Union, for foreign affairs and security policy, to supply expertise in the field of EU relations with the third countries, including a department of analysis of immigration (which, among other attributions of prospective analysis, identifies typical and atypical causes for 
foreign vulnerabilities of the EU and to monitor their evolution - such as massive population exoduses)

- Foundation of European offices for counselling the third states, regarding the methods to manage the special funds given by the $E U$, for the refugees and immigrants, for the funds to reach these countries (in a consolidated European policy regarding the asylum and immigration, extended to covering such situations)

- Foundation of a Special European Fund of Support for the Refugees (for the latter to be encouraged to remain in buffer-countries, considered "safe", such as Turkey, Jordan, Iran etc. and to stop migrating in massive waves, to Europe).

- Foundation of special European funds destined directly for the safe third countries, especially for the reception, provision of shelter, economic integration of immigrants and war refugees (creation of jobs, cities of refugees, encouragement and location of European or mixed companies, in the area of these states, and generation of regional economies, in which the refugees and the immigrants have jobs, for them not to see themselves in the position of massively migrating to Europe).

- Foundation of a European Quick Support Body for the Refugees in safe countries and inside the $\boldsymbol{E U}$ (for the direct management of the situation, at European level, with European bodies and funds)

- Foundation of a European body for the salvation of immigrants whose lives are endangered on account of the transborder crime and trafficking (European Body for the Support of Immigrants in Situations that endanger their Lives, on account of these networks).

- Setup of European databases of immigrants and of an European Authority for the Collection, Recording and Management of Personal Data of the Immigrants and Refugees entering or about to enter Europe, following the massive waves of migration towards Europe. The Authority will be endowed with the competence of identifying the immigrants' origin, real identity, their purpose of entering into the EU and also, with the competence of identifying the people who belong to networks of transborder crime or terrorist networks, involved in "the crisis of immigrants"

- Setup of a European Special Corps for Counter-Trafficking of People, in case of massive flow of immigrants in the EU. 


\section{Conclusions}

As noted, although EU underwent several crises (from the democratic deficit, rejection of the constitutional treaty, global economic crisis in 2009, to the crisis in Greece), none of these crises was this close to jeopardize the very stability and coherence of the entire EU, as the crisis of immigrants. Therefore, the role of the EU diplomacy must be consolidated, diversified, considering all the aspects presented above, in order to support the self-assumed role of the EU, through the founding treaty from Lisbon, that of playing on the international scene of the $21^{\text {st }}$ century, as "global actor", among the great actors of the world.

\section{REFERENCES}

Juncker, J. C., Foster, P., Holehouse, M. (2015). Juncker calls for 'compulsory' redistribution of 160,000 migrants. Available online at: www.telegraph.co.uk/news/worldnews/europe/eu/11852782/JeanClaude-Juncker-State-of-the Union-EU-adress-refugees-crisislive.html, accessed on September $9^{\text {th }} 2015$

Juncker, J.-C. (2015). State of The Union 2015: Time for Honesty, Unity and Solidarity, Strasbourg, September $9^{\text {th }}$ 2015. Available online at: http://europa.eu/rapid/press-release SPEECH-15-5614 en.htm, accessed on September $20^{\text {th }} 2015$

Decision of EU Council no. 11665/10, dated July 20 2010 , Brussels, on the organization and operation of EAES

Resolution of the European Parliament no. P7_TA (2009)0057, „The institutional aspects of setting up the European External Action Service" (2009/2133(INI)), dated October $22^{\text {nd }} 2009$.

\section{Acknowledgment}

The present article represents only the personal opinion of the author and it does not involve in any form any other natural person or legal entity. All the rights over the present text are reserved. The quotations from the present text are made by mentioning the author and the complete source. 


\section{Biodata}

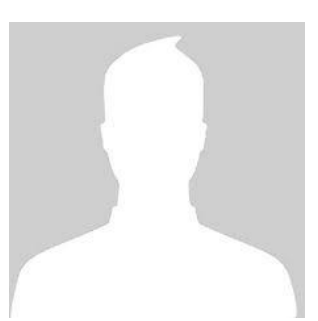

Mădălina Virginia ANTONESCU holds a Ph. D. in European Law, at Bucharest University, Department of Law (2009) and she is scientific researcher. At present, she is counsellor with Romanian Diplomatic Institute and honorary researcher with Romanian Institute for Human Rights. She holds a diploma of Paris I Pantheon Sorbonne University (1998) and a master of National School for Political and Administrative Studies, Bucharest, specialization "International relations and European integration" (20012003). Fields of interest: human rights, European law, international law, international relations, diplomacy, culture, civilization. 